\title{
Design Information Consentpasiment Competition Of Desktop Based Dental Poly Information System In Palkesmas Talagabodas Bandung
}

\author{
Yudhi Yanuar', Lilis Emalia ${ }^{2}$, Novia Surya Ghani ${ }^{3}$ \\ ${ }^{1}$ Information Management Study Program Politeknik Piksi Ganesha Bandung \\ ${ }^{2}$ Information Management Study Program Politeknik Praktisi Bandung \\ yudhiyanuar2010@gmail.com, lilis.emalia@gmail.com
}

\begin{abstract}
The research aims to know the design of system information completeness of charging the informed consent of the patient's Poly. teeth to use microsoft Visual Studio 2010 in UPT Puskemas Talagabodas the city of Bandung. The research method used is the method of qualitative techniques of collecting data field studies, interviews, the library and browsing the internet. Methods of use is a waterfall. From a study found no problems, namely: The process of completwness analysis of charging the informed consent is still not running, The informed consent in Poly. teeth are not filled with complete, the lack of socialization of the creation and filling the informed consent, especially in Poly. teeth. The advice is give, namely: start to do the analysis of the completeness of charging the informed consent in accordance with SOP, the medical records that there can be re-socialization back about the creation and filling the informed consent to all staff of other medical right to send out the, should the institution has a system information that can rock the performance of staff medical records more effective in terms of analyzing the completeness of the informed consent and facilitate the creation of the, quipment.
\end{abstract}

Keywords: Design, Information System, Informed Consent Completness, Microsoft Visual Studio 2010.

\section{Introduction}

The Community Health Center, in short the Puskesmas, is a functional organization that is comprehensive, integrated, equitable, acceptable and affordable to the community, with the active participation of the community. Based on the understanding of the Puskesmas, it can be seen that the Puskesmas has a very beneficial role for the surrounding community because its function in addition to serving medicine also provides employment for the surrounding community. Information and communication technology that has developed so rapidly in various sectors, including in the health sector. One application is the electronic health record.

One of the medical record files containing information about the patient's approval of each medical action provided by health workers in hospitals, health centers or other health services to patients contained in the informed consent or medical action approval sheet. With the informed consent of the patient can be legally protected from arbitrary doctors. In addition, informed consent is also important to provide legal protection against the implementation of medical actions from the demands of the patient who are not fair, as well as the consequences of unexpected negative medical actions. One of the patient services at UPT Talagabodas Health Center in Bandung City is the Dental Polyclinic, in which the patient has a special medical record number and is different when the patient registers at another poly service. So that in the dental clinic there is a separate 
medical record file specifically for dental poly patients. Based on observations made at the UPT Talagabodas Health Center in Bandung, in the process of completeness analysis the filling of the Informed Consent form in the dental clinic has not been specifically done and the data processing is still done manually and incomplete in filling it, causing the results of the report to be ineffective and accurate.

\subsection{Principal Problems}

Based on the background above, then the main issues that will be discussed in this study are:

a) In filling out an informed consent form which is often incomplete.

b) The analysis process has not been carried out specifically so that there has been no report on the completeness of the filling that shows in detail the format of the informed consent form which is often incomplete.

\subsection{Research Objectives and Benefits}

a) To find out the procedure for filling out an informed consent form on dental poly patients at UPT Talagabodas Health Center.

b) To find out what are the obstacles faced by the officer analyzing the completeness of the informed consent form for dental patients in UPT Talagabodas Health Center.

c) To find out what efforts must be made to overcome the problem of filling out the informed consent form.

\subsection{Research Benefits}

a) For Authors

Adding insight and knowledge in the field of health, especially in the field of medical records regarding the completeness analysis system for filling out informed consent forms Knowing the difference between theories during lectures that are learned with direct practice in the field. So that adds to the experience for writers.

b) For Academics

Increasing library treasury to enrich knowledge and references regarding medical records related to informed consent and can be used as a source of information for students majoring in Medical Record Informatics at Piksi Ganesha Polytechnic Bandung.

c) For Puskesmas

This report is expected to provide input through thought contributions in the development of the medical record system, specifically the analysis section of completeness of filling out the informed consent form of dental poly patients at UPT Talagabodas Health Center.

\section{Research Methodology}

\subsection{Research Methodology}

In completing this thesis the authors used a qualitative research with a descriptive approach by describing the situation that occurred in the field, especially regarding the analysis of the completeness of the informed consent form filling in UPT Talagabodas Health Center in Bandung and comparing the existing theories then making the design of the complete information system filling the informed consent form using Microsoft Visual Studio 2010. The research method that will be used is qualitative research method, this research which does not emphasize the calculation of numbers in giving weight to its assessment of problems but by analyzing and understanding existing work processes. Descriptive method is a method of research carried out with the main objective to make a picture or description of a situation objectively. 


\subsection{Data Collection Techniques}

Data collection techniques are the most strategic step in research, because the main purpose of research is to obtain data, including:

a) Interview Technique

According to Esterberg in Sugiyono (2013) interview is a meeting of two people to exchange information and ideas through questions and answers, so that meaning can be constructed in a particular topic.

b) Observation Technique

Sutrisno Hadi in Sugiyono (2013) argues that, observation is a complex process, a process that is composed of various biological and psychological processes. Two of the most important are the processes of observation and memory.

c) Library Study Techniques

According to M. Nazir library study technique is a data collection technique by conducting a study of the review of books, literature, notes, and reports that have to do with the problem being solved.

\subsection{Software Development Methods}

In designing this system the author uses the development of the waterfall model system because the waterfall model has many advantages in accordance with the design of the system that the author designed both in terms of time used, this method allows for departmentation and control. The process of developing a one by one phase model, thus minimizing errors that might occur. Development moves from concept, through design, implementation, testing, installation, problem solving, and ending in operation and maintenance.

\section{Results and Discussion}

\subsection{Problems encountered}

a) Many of the special medical approval records in the dental clinic were not filled in.

b) There is no completeness analysis activity yet for completing the informed consent form

c) Lack of medical record staff and socialization responsibilities regarding the completeness of procurement of special medical records of consent forms for all those involved in filling them out.

\subsection{Suggested Effort}

a) With the establishment of an information system for completeness analysis, filling out an informed consent form in dental clinics will strive to assist medical record staff in analyzing the completeness of informed consent and immediately produce a date, report, patient, physician, supplementary and incomplete report.

b) Re-socializing the standard operating procedures in making and filling out informed consent forms. 
1) Informed Consent completeness flowmap

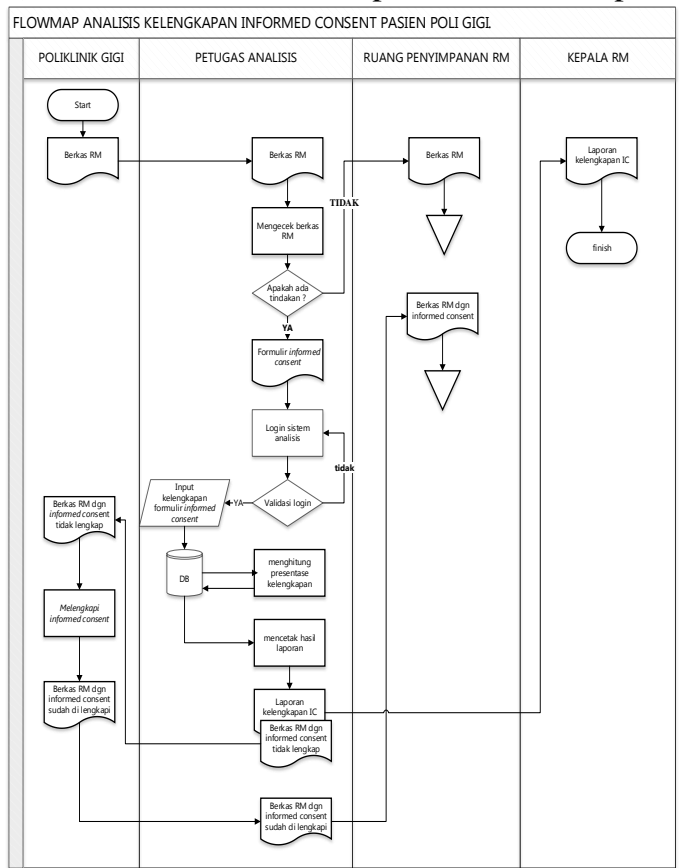

Figure 1. Flowmap designed

3) Table Relations

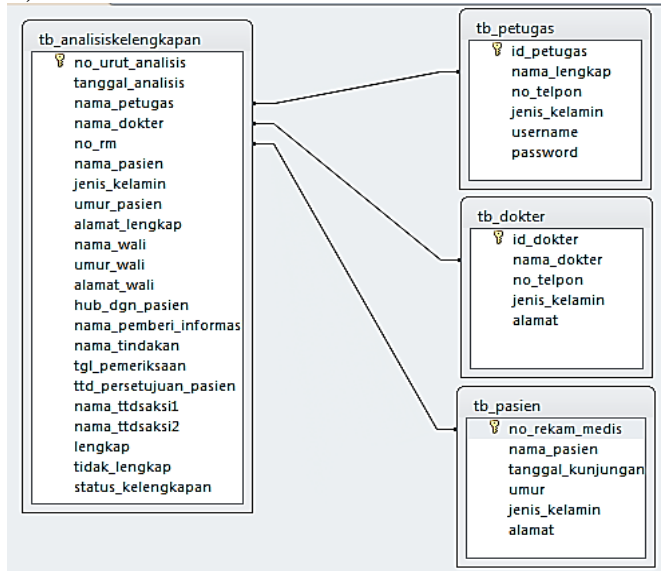

Figure 3. Table Relationships

5) Display Form Completeness Analysis

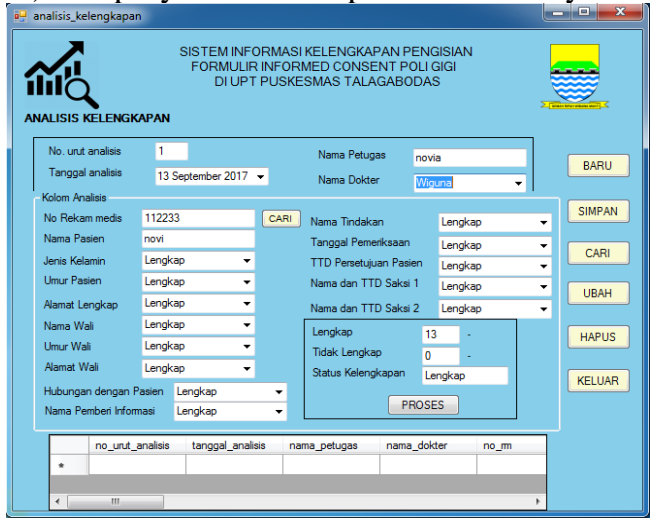

Figure 5. Display Form Completeness Analysis Diagram
2) Entity Relantionship Diagram

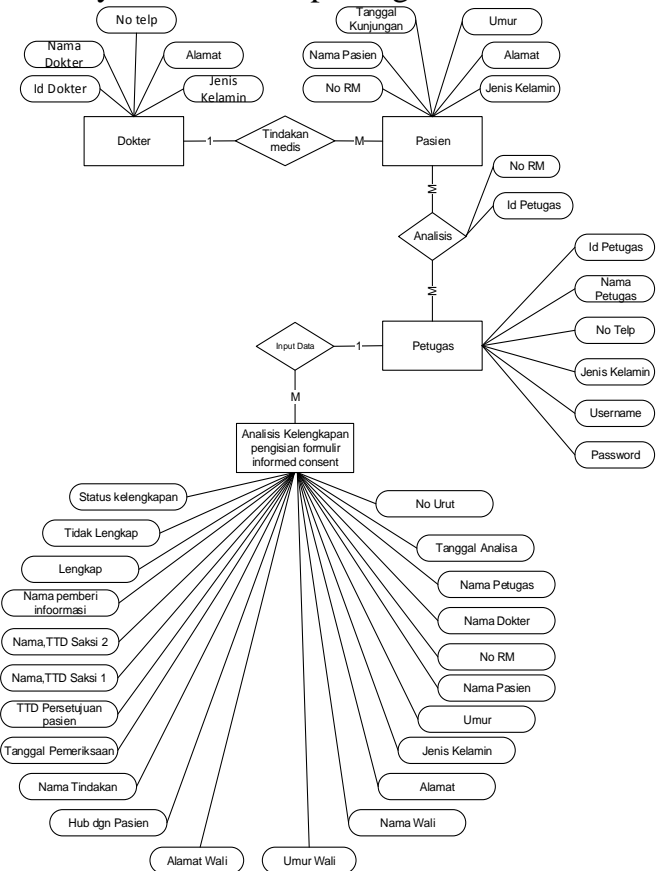

Figure 2. Entity Relantionship Diagram

4) Context Diagram

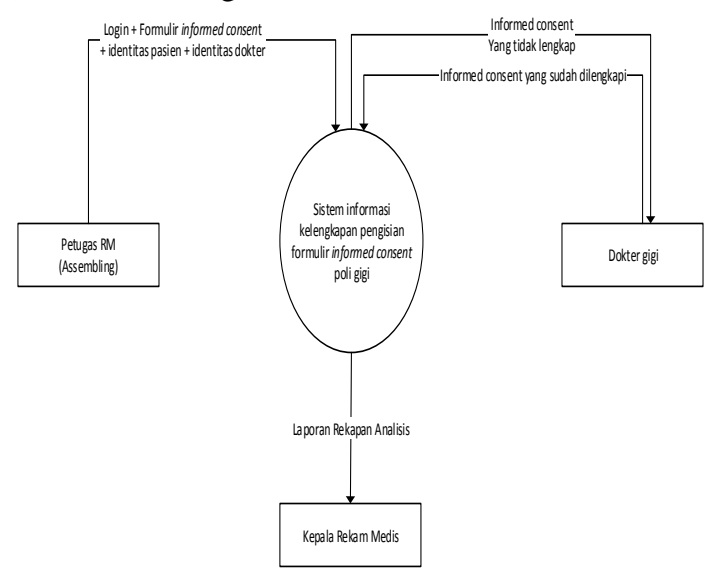

Figure 4. Context Diagram

6) Display Menu Report

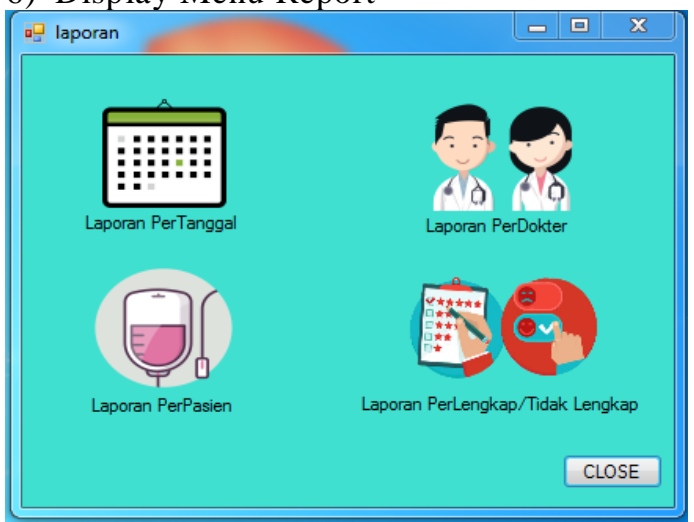

Figure 6. Display the Report Menu 


\section{Conclusion}

Based on the results of research that has been done by the writer at UPT Talagabodas Health Center. Then the authors can make conclusions including:

a) In the medical record form especially the informed consent that is in the dental clinic there are still many who are not equipped in filling this out, it is very unfortunate because given that the informed consent has legal aspects or as evidence of patient approval for medical action to be performed by a doctor.

b) The absence of completeness analysis activities for completing the informed consent form is certainly very unfortunate because for some time to come the UPT Talagabodas Puskesmas will accredit the Puskesmas of bandung in the city of Bandung to increase the quality or the quality of the medical record file

c) he medical record staff in the UPT Talagabodas Health Center is very limited, of course, this is very lacking because the medical record activities are not small.

d) Lack of socialization regarding the importance of completeness of filling out medical record files especially the informed consent form to all those involved in filling it out.

e) In searching for the old patient's medical record file, the officer still has difficulty in finding the existence of the medical record file and requires a long time.

Some suggestions that could be taken into consideration for the puskesmas are:

a) We recommend that the puskesmas have a complete information system for completing an informed consent form by computerization to help analyze the completeness of the informed consent form in order to minimize the existing problems. In addition, it can facilitate the medical records officer in terms of analyzing and making reports more effectively.

b) We recommend that the existing medical record officer can re-socialize about SOP (Standard Operating Procedure) in the preparation and filling of informed consent forms, especially in the dental clinic of Talagabodas puskesmas so that they can better understand the importance of making and filling informed consent forms for the institution and a patient.

\section{References}

[1] Departemen Kesehatan Republik Indonesia, 2006, Pedoman Pengelolaan Rekam Medis di Indonesia revisi II, jakarta: Dirjen Yanmed.

[2] Fathansyah (2002). Basis Data. Informatika. Bandung.

[3] Hatta, Gemala R. (2008). Pedoman Manajeman Informasi Kesehatan disarana Pelayanan Kesehatan Revisi II. Universitas Indonesia.Jakarta.

[4] Jogiyanto. (2005). Analisis dan Desain Sistem Informasi. Yogyakarta.

[5] Ladjamudin, bin Al-Bahra. (2005). Analisis dan Desain Sistem Informasi. Graha Ilmu. Yogyakarta.

[6] Ladjamudin, bin Al-Bahra. (2013). Analisis dan Desain Sistem Informasi.Graha Ilmu.Yogyakarta.

[7] Pressman, Roger S. (2012). Rekayasa Perangkat Lunak - Buku Satu, Pendekatan Praktisi (Edisi 7). Yogyakarta. Andi.

[8] Sutabri, Tata. (2012). Analisis sistem Informasi. Yogyakarta: Penerbit Andi

[9] Sugiyono.( 2013). Metode Penelitian Kuantitatif, Kualitatif dan $R \& D$. Alfabeta, CV. Bandung.

[10] Standar Akreditasi Puskesmas, Tahun Tentang rencana tindakan dan pengobatan serta rencana layanan terpadu. 


\section{Authors}

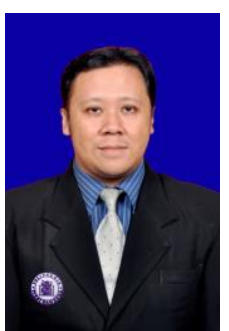

$\mathbf{1}^{\text {st }}$ Author

Yudhi Yanuar

Information Management Study Program Politeknik Piksi Ganesha Bandung 